\title{
Rapid gentamicin assay by enzymatic adenylylation
}

\author{
ELISABETH TEN KROODEN AND J. H. DARRELL \\ From the Department of Bacteriology, Royal Postgraduate Medical School, London
}

SYNOPSIS A method is described for the assay of gentamicin using the enzyme gentamicin adenylyltransferase derived from an R-factor-carrying strain of Escherichia coli. The reaction involves adenylylation of the gentamicin with $\left({ }^{14} \mathrm{C}\right)-$ ATP to form a radioactively labelled product. The technique is compared with the plate diffusion and the urease methods. The adenylylation technique N gives results comparable to the plate diffusion assay and is more accurate than the urease method.

The aminoglycoside antibiotics are a valuable group in the treatment of both tuberculous and nontuberculous infections. Gentamicin has been recommended in combination with other antibiotics as initial treatment for undiagnosed septicaemia (Darrell and Neale, 1972) and in at least some cases of endocarditis (Ruhen and Darrell, 1973). The only limiting factor in their use is their ototoxicity. The danger is potentially greatest in patients with impaired renal function. These tend to form a high proportion of those patients in whom these drugs are needed. It is therefore vital that microbiology departments are able to determine blood levels of aminoglycosides-in fact it is probably the only group of antibiotics for which this is unquestionably necessary.

In the past blood levels have been assayed using a microbiological method requiring overnight incubation. This method can be modified to give a result in about five hours but this time interval represents one dose period in clinical use and does not fit ideally into laboratory routine. Noone, Pattison, and Samson (1971) described a rapid method based on the inhibition by gentamicin of urease activity of Proteus.

Benveniste and Davies (1971) showed that gentamicin could be inactivated by an enzyme produced by an R-factor-carrying strain of Escherichia coli. The enzyme, released by osmotically shocking the cells, adenylylates the gentamicins and several related aminoglycosides. This reaction has been applied in a rapid assay for gentamicin which uses $\left({ }^{14} \mathrm{C}\right)$-ATP and measures the amount of $\left({ }^{14} \mathrm{C}\right)$ -adenylylated-gentamicin produced (Smith, Van Otto, and Smith, 1972). An initial investigation into the method and its clinical application are described.

Received for publication 15 March 1974.

\section{Materials and Methods}

ADENYLYLATION METHOD

Escherichia coli W677/JR66 (Benveniste and Davies, 1971) was used as the enzyme source. It was maintained on nutrient agar slopes containing $10 \mu \mathrm{g} / \mathrm{ml}$ gentamicin. Mutants resistant to $1500 \mu \mathrm{g} / \mathrm{ml}$ kanamycin were used to select for resistance to $300 \mu \mathrm{g} / \mathrm{ml}$ gentamicin on plates containing this antibiotic.

\section{CULTURE MEDIUM}

A stock salt solution was prepared by dissolving $\begin{array}{llllll}60 \mathrm{~g} & \mathrm{Na}_{2} & \mathrm{HPO}_{4} & \text { (anhydrous), } 30 \mathrm{~g} & \mathrm{KH}_{2} \mathrm{PO}_{4}\end{array}$ (anhydrous), $5 \mathrm{~g} \mathrm{NaCl}, 10 \mathrm{~g} \mathrm{NH}_{4} \mathrm{Cl}$ in 1 litre deionized water, sterilized by autoclaving. The culture medium, a modification of the M9 medium (Clowes and Hayes, 1968), consisted of a 1 in 10 dilution of stock salt solution, $0.2 \%$ glycerol, $1 \times 10^{-3} \mathrm{M} \mathrm{MgSO}_{4}$ (sterile), $1 \times 10^{-4} \mathrm{M} \mathrm{CaCl}_{2}$ (sterile), $0.5 \%$ Bactopeptone (Difco) and $3 \mathrm{mg} / \mathrm{l}$ thiamine.

\section{BUFFER SOLUTION}

Tris (hydroxymethyl) aminomethane buffer was adjusted to the required $\mathrm{pH}$ with concentrated $\mathrm{HCl} / \mathrm{N}$ at room temperature, although it could be used at $a_{N}$ different temperature.

\section{STANDARDS}

Gentamicin (Genticin, Scherring) standards containing $2 \cdot 5,5 \cdot 0,10 \cdot 0$, and $15 \cdot 0 \mu \mathrm{g} / \mathrm{ml}$ were prepared in pooled normal human serum and stored frozen.

\section{$\left({ }^{14} C\right)-A T P$}

Adenosine -C14(U)-5'-triphosphate (CFB 91) was obtained from the Radiochemical Centre, Amersham. It was diluted with $1.6 \mathrm{mM}$ unlabelled ATP to give a specific activity of $2.5 \mu \mathrm{Ci} / \mu$ mole. 
SCINTILLATION FLUID

This contained $7 \mathrm{~g}$ butyl-PBD (2(4'-tert-butylphenyl), 5-(4"-biphenylyl)-1,3,4-oxadiazole) (Intertechnique) per litre of toluene (Analar).

PHOSPHOCELLULOSE DISCS

Discs, $20 \mathrm{~mm}$ in diameter, were cut from Whatman P81 chromatography paper.

\section{ENZYME EXTRACTION}

The release of the enzyme by osmotic shock is a selective process (Heppel, 1967). In the hypertonic sucrose solution the cytoplasm recedes from the cell wall. When the external osmotic pressure is suddenly reduced by suspending the cells in $5 \times 10^{-4} \mathrm{M} \mathrm{Mg}$ $\mathrm{Cl}_{2}$, the cells expand, the plasmolysis space disappears and the enzyme is expelled, within a minute. Growing cells are thought to be more susceptible to osmotic shock (Nossal and Heppel, 1966).

An inoculum of $1 \mathrm{ml}$ of an overnight broth culture was added to $100 \mathrm{ml}$ of modified M9 medium. The culture was incubated for approximately four hours at $37^{\circ} \mathrm{C}$, in a shaking waterbath to obtain good aeration, until the late log phase was reached. It then had an optical density of 0.2 at 550 $\mathrm{m} \mu$ and a cell density of approximately $10^{7}$ viable units $/ \mathrm{ml}$. The cells were harvested by centrifugation at room temperature and washed twice with $40 \mathrm{ml}$ $0.01 \mathrm{M}$ Tris-HCL- $0.03 \mathrm{M} \mathrm{NaCl}, \mathrm{pH} \mathrm{7.8}$. The cell pellet was resuspended in $20 \mathrm{ml} 20 \%(\mathrm{w} / \mathrm{v})$ sucrose$0.03 \mathrm{M}$ Tris-HCL-0.003 M EDTA, pH 7.3, and stirred for $15 \mathrm{~min}$ at room temperature using a magnetic stirrer. The suspension was centrifuged at $4^{\circ} \mathrm{C}$ at $10000 \mathrm{~g}$ for $10 \mathrm{~min}$ and the supernatant discarded. The tube was drained and carefully wiped to remove any sucrose. The pellet was rapidly dispersed in $4 \mathrm{ml}$ ice-cold $\mathrm{MgCl}_{2}\left(5 \times 10^{-4} \mathrm{M}\right)$ and stirred for $10 \mathrm{~min}$ in an ice bath. The suspension was centrifuged at $4^{\circ} \mathrm{C}$ at $26000 \mathrm{~g}$ for 10 minutes. The enzyme is oxygen labile, but could be stored in the presence of the reducing agent, dithiothreitol, for at least six weeks at $-70^{\circ} \mathrm{C}$ without loss of activity. This was added to the supernatant ('osmotic shockate') to give a $1 \mathrm{mM}$ solution, which was stored in $1 \mathrm{ml}$ volumes at $-70^{\circ} \mathrm{C}$.

\section{ADENYLYLATION ASSAY}

There are two steps to the assay procedure. First, the formation of the radioactively labelled gentamicinadenylyl complex by transferring the $\left({ }^{14} \mathrm{C}\right)$-adenylyl (AMP) residue from ! $\left({ }^{14} \mathrm{C}\right)-\mathrm{ATP}$ onto the aminoglycoside; and second, the separation and detection of this complex, which binds selectively to the phosphocellulose paper.

The method was based on that of Smith, Van Otto, and Smith (1972), illustrated diagrammatically

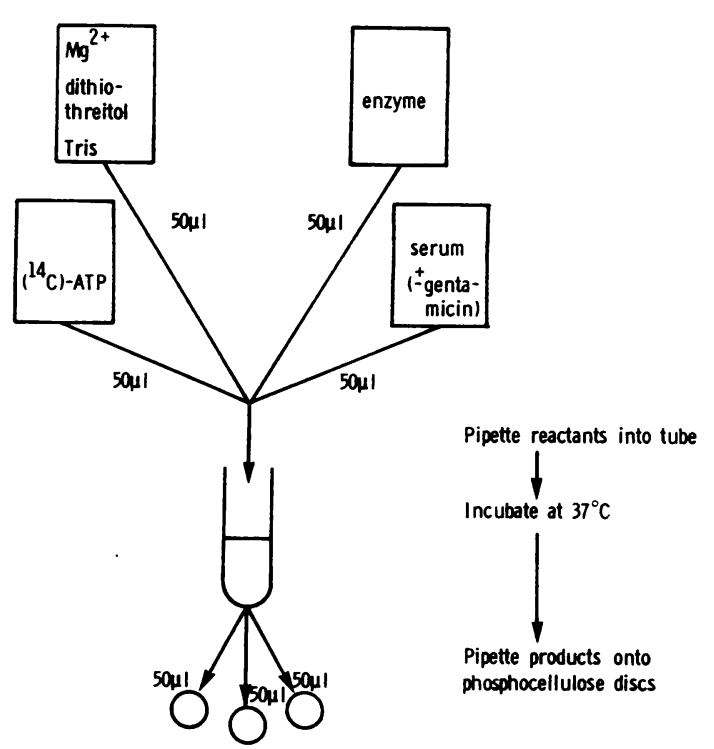

Fig 1 Diagrammatic representation of adenylylation assay method.

in figure 1. The reaction mixture consisted of $50 \mu \mathrm{l}$ of each of the following: test serum $0.2 \mathrm{M}$ TrisHCL- $0.032 \mathrm{M} \mathrm{MgCl} 2-0.04 \mathrm{M}$ dithiothreitol, $\mathrm{pH}$ $8.1 ; 1.6 \mathrm{mM}\left({ }^{14} \mathrm{C}\right)-\mathrm{ATP}$; and enzyme. Dithiothreitol was made up freshly in the buffer on each occasion. The mixture was incubated at $37^{\circ} \mathrm{C}$ for a sufficient length of time to complete the reaction. Fifty $\mu$ l was then pipetted onto each of three phosphocellulose paper discs which were allowed to dry briefly. The discs were then washed to remove unreacted $\left({ }^{14} \mathrm{C}\right)-\mathrm{ATP}$ and the other reactants, none of which bind to the paper. The removal of $\left({ }^{14} \mathrm{C}\right)-$ ATP was more efficient if the discs were washed in 5 mM Tris-HCl buffer, pH 7.4 (Forrey, Blair, O'Neil, Cut er, and Christopher, 1973) than in distilled water (Benveniste and Davies, 1971); and also if the first wash for two min at $70^{\circ}-80^{\circ} \mathrm{C}$ was followed by a minimum of four rinses in the buffer at room temperature, with rapid swirling in a conical flask. The discs were then dried under an infrared lamp and transferred to vials containing $5 \mathrm{ml}$ scintillation fluid. They were counted in a scintillation counter (Intertechnique ABAC SL40) for a time dependent upon the radioactivity present. To allow for nonspecific binding for $\left({ }^{14} \mathrm{C}\right)-$ ATP to the discs, control tubes, containing serum without gentamicin, were included in each batch. Statistical analysis showed the greatest variation to be between the three discs from any one tube. It was therefore necessary to duplicate the entire assay of both standards and test sera and to ensure accurate pipetting. 
PLATE ASSAY

Plate diffusion assays were performed as described by Reeves (1972) modified by surface seeding plates with a $10^{-3}$ dilution of an overnight culture of a Klebsiella-Enterobacter (NCTC 10896) strain and incubating for 18 hours. Four replicates of the same range of standards and of each test serum were tested.

\section{UREASE METHOD}

The method described by Noone, Pattison, and Samson (1971) and modified by Noone, Pattison, and Slack (1972) was used.

\section{Results}

\section{STANDARD CURVE}

Gentamicin standards and the control were assayed in duplicate with $\left({ }^{14} \mathrm{C}\right)-\mathrm{ATP}$ at a specific activity of $2.5 \mu \mathrm{Ci} / \mu$ mole. Fifty $\mu \mathrm{l}$ of the product of the reaction was spotted onto each of three discs, washed, dried, counted, and the average of the three discs taken. A regression line relating the radioactivity bound to a disc to the amount of gentamicin present was calculated. The amount of gentamicin in a test serum is read from the standard curve (fig 2).

The slope of the standard curve obtained with the same enzyme, gentamicin standards, and $\left({ }^{14} \mathrm{C}\right)$-ATP remained the same for seven weeks. Thus one standard curve could be used repeatedly to read the gentamicin content of specimens from the phosphocellulose-bound radioactivity, corrected for the counts in a control serum, assayed at the same time.

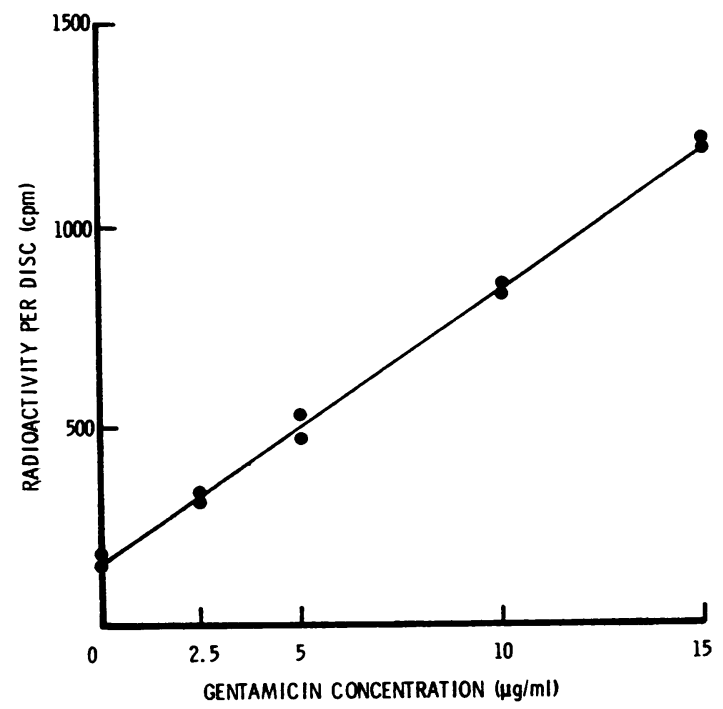

Fig 2 Standard curve.

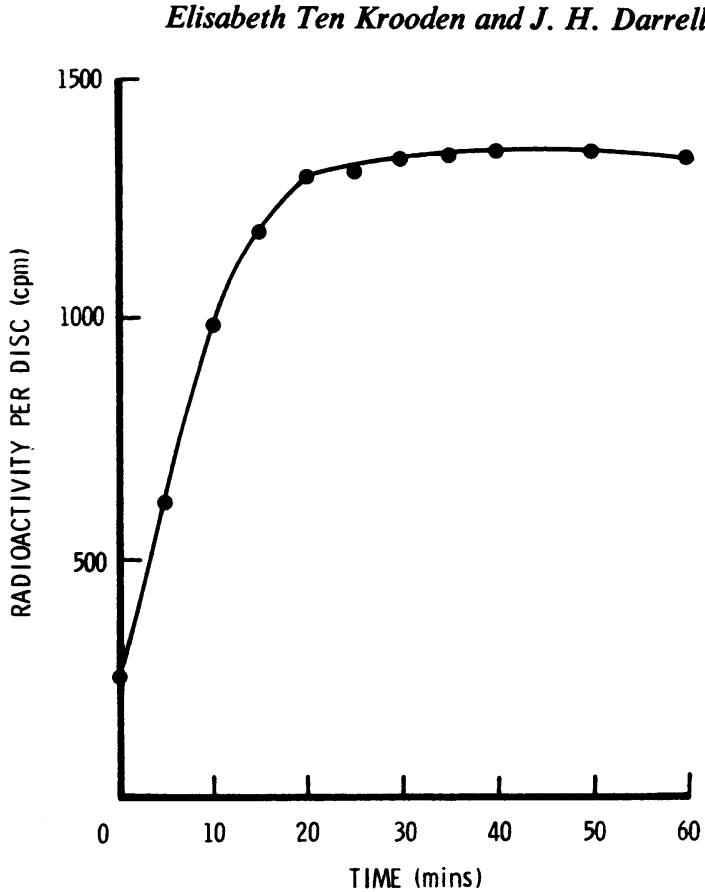

Fig 3 Time course of reaction.

TIME COURSE OF REACTION

With each new enzyme preparation, serum containing $15 \mu \mathrm{g} / \mathrm{ml}$ gentamicin was assayed for different lengths of time. The time course of the reaction is shown in figure 3 . This demonstrates that the reaction with $15 \mu \mathrm{g} / \mathrm{ml}$ gentamicin, which is more than the amount normally found in serum in clinical practice, was completed in $\mathbf{3 0}$ minutes.

ESTIMATE OF TIME TAKEN TO ASSAY

GENTAMICIN

A comparison was made between adenylylation and urease methods (table I). It was assumed that the time taken to thaw reactants and pipette them into tubes and to calculate and plot results was the same for both methods. The counting time was $\tilde{N}$ based on the time taken to count the radioactivity in $N$ control, 5 , and $10 \mu \mathrm{g} / \mathrm{ml}$ standards, and one test specimen, assayed in duplicate with $\left({ }^{14} \mathrm{C}\right)$-ATP at $2.5 \mu \mathrm{Ci} / \mu$ mole, ensuring that the standard error of counting was approximately 1 . With $\left({ }^{14} \mathrm{C}\right)$-ATP at $\stackrel{\varrho}{=}$ $5 \mu \mathrm{Ci} / \mu$ mole counting time was reduced to 66 minutes. The inclusion of another test specimen in the above assay would add 24 minutes to the counting time, whereas a completely separate assay would be $\vec{\Phi}$

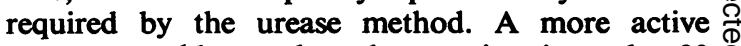
enzyme would complete the reaction in under 30 minutes. A disadvantage of the adenylylation method is that the technician is occupied much of the time 


\begin{tabular}{|c|c|c|c|}
\hline \multicolumn{2}{|l|}{ Adenylylation } & \multicolumn{2}{|l|}{ Urease } \\
\hline Procedure & $\begin{array}{l}\text { Time } \\
(\min )\end{array}$ & Procedure & $\begin{array}{l}\text { Time } \\
\text { (min) }\end{array}$ \\
\hline $\begin{array}{l}\text { Incubation with enzyme } \\
\text { Pipetting products onto discs; washing and drying discs } \\
\text { Counting time' } \\
\text { Control } \\
\text { Two standards } \\
\text { One test }\end{array}$ & $\begin{array}{l}30 \\
40 \\
60 \\
36 \\
24\end{array}$ & $\begin{array}{l}\text { Incubation with Proteus } \\
\text { Measurement of } \mathrm{pH}\end{array}$ & $\begin{array}{r}90 \\
5\end{array}$ \\
\hline Total & 190 & Total & 95 \\
\hline
\end{tabular}

Table I Estimate of time taken to assay gentamicin

${ }^{1}$ Counting time is reduced to a total of $66 \mathrm{~min}$ with $\left({ }^{14} \mathrm{C}\right)-\mathrm{ATP}$ at $5 \mu \mathrm{Ci} / \mu \mathrm{mole}$. Total time is then $136 \mathrm{minutes}$.

whereas with the urease method he would be freed for other activities during the incubation time of 90 minutes.

\section{COMPARISON OF METHODS FOR ASSAYING GENTAMICIN}

Twenty-five sera from patients receiving gentamicin were assayed by plate diffusion and adenylylation methods. The results are compared in figure 4. A regression line was drawn by the method of least squares. The slope of the line was $1.12 \pm 0.062$, showing that the plate assay tended to give slightly higher results than the adenylylation method. The coefficient of correlation was 0.95 ( $\mathrm{P}<0.001$ ). Twenty of the same specimens were assayed by plate diffusion and urease methods (fig 5). The slope of the regression line was $0.98 \pm 0.05$ and the coefficient of correlation was $0.82(\mathrm{P}<0.001)$.

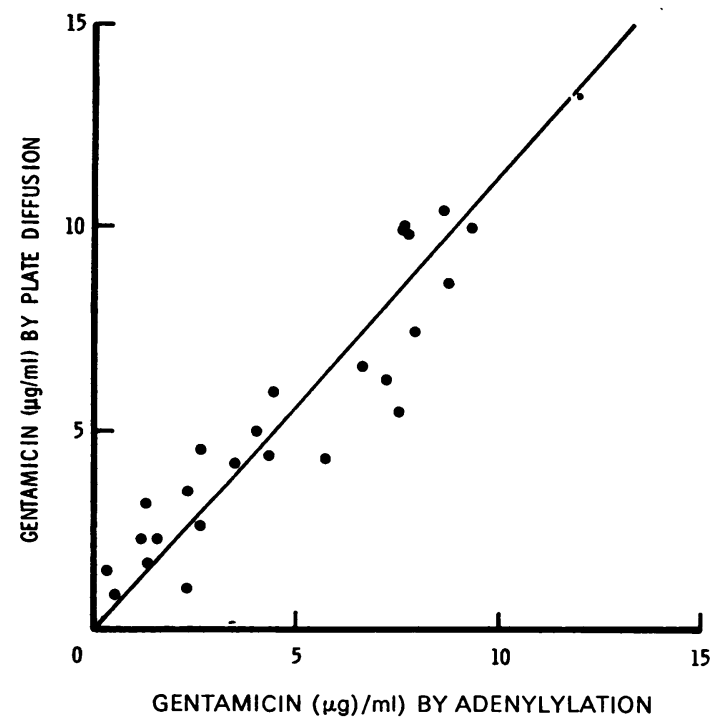

Fig 4 Comparison of adenylylation and plate assay methods for estimating gentamicin in serum.
REPRODUCIBILITY

The reproducibility of assay by adenylylation, plate diffusion, and urease methods is recorded in table II. The adenylylation method was significantly more accurate than the urease method $(P \simeq 0.01)$. There was no significant difference in accuracy between the plate diffusion and adenylylation methods. An example of the reproducibility of the adenylylation method is given in table III. Specific

\begin{tabular}{llll}
\hline Assay Method & $\begin{array}{l}\text { No. of Sera } \\
\text { Assayed }\end{array}$ & $\begin{array}{l}\text { No. of Degrees } \\
\text { of Freedom }\end{array}$ & $\begin{array}{l}\text { Standard } \\
\text { Deviation } \\
\text { within Sera }\end{array}$ \\
\hline Adenylylation & 27 & 59 & 0.66 \\
Plate diffusion & 13 & 16 & 0.77 \\
Urease & 8 & 11 & $1 \cdot 10$ \\
\hline
\end{tabular}

Table II Comparison of reproducibility of assay methods

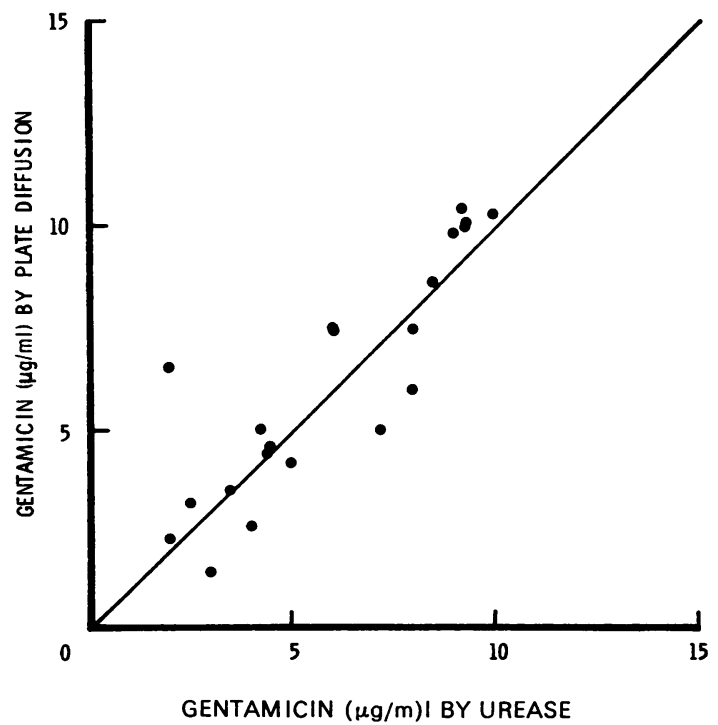

Fig 5 Comparison of urease and plate assay methods for estimating gentamicin in serum. 


\begin{tabular}{|c|c|c|c|}
\hline $\begin{array}{l}\text { Expected } \\
\text { Concentration } \\
(\mu \mathrm{g} / \mathrm{ml})\end{array}$ & $\begin{array}{l}\text { Estimated } \\
\text { Concentration } \\
(\mu \mathrm{g} / \mathrm{ml})\end{array}$ & Mean & $\begin{array}{l}\text { Standard } \\
\text { Deviation }\end{array}$ \\
\hline 3.0 & $\begin{array}{l}3 \cdot 1 \\
2 \cdot 7 \\
2 \cdot 4 \\
3 \cdot 6 \\
2.7 \\
2 \cdot 2 \\
2 \cdot 2 \\
2 \cdot 7\end{array}$ & $2 \cdot 70$ & 0.47 \\
\hline $5 \cdot 0$ & $\begin{array}{l}4 \cdot 3 \\
4 \cdot 5 \\
5 \cdot 9 \\
6 \cdot 0 \\
5 \cdot 0 \\
5 \cdot 0 \\
5 \cdot 1 \\
4 \cdot 0\end{array}$ & 4.97 & 0.71 \\
\hline $6 \cdot 5$ & $\begin{array}{l}6 \cdot 7 \\
6.8 \\
8.0 \\
8.1 \\
7 \cdot 4 \\
7 \cdot 3 \\
7 \cdot 0 \\
7 \cdot 1\end{array}$ & $7 \cdot 30$ & 0.51 \\
\hline $12 \cdot 0$ & $\begin{array}{l}12.4 \\
12.7 \\
10.8 \\
10.6 \\
11.4 \\
11.8 \\
11.7 \\
11.5\end{array}$ & 11.61 & 0.72 \\
\hline
\end{tabular}

Table III Assay of gentamicin by adenylylation method

amounts of gentamicin were added to pooled normal human serum and were assayed on eight occasions.

\section{Discussion}

The most important single point in the use of aminoglycosides is that potential toxicity should be recognized and some effort should be made logically to modify dosage in renal failure. Overnight assay methods work tolerably well but the clinician having taken a specimen is faced with the decision whether to continue treatment and risk overdosage or to withhold treatment which is required until the assay result is available. In fact, the greatest risk is undertreatment.

The adenylylation method has several advantages. It is based on a well understood and specific biochemical reaction (Benveniste and Davies, 1973). Gentamicin can be assayed irrespective of the presence of other antibiotics, other than related aminoglycosides, in the serum. The method has been found to be as accurate as the widely used plate diffusion assay and more accurate than the urease method. It also has the advantage over the urease method that there is a linear relationship between gentamicin concentration and product formation. The time taken to perform an assay can be reduced considerably if $\left({ }^{14} \mathrm{C}\right)$-ATP of a higher specific ${ }^{\circ}$ activity is used together with a more active enzyme preparation. Nevertheless, the procedure takes longer than the 60 minutes quoted by Smith, Van Otto, and Smith (1972) and demands the attention of the technician for most of the time whereas the urease and plate diffusion assays require less time to be expended on actual bench work. The method is particularly useful if more than one specimen is to $\mathrm{N}$ be assayed, as these can be processed together. The $O$ applicability of the method obviously depends on the facilities available in a bacteriology laboratory $c$ as sophisticated equipment, such as a scintillation counter, and some technical skill are required to prepare the enzyme and to perform the assay procedure.

We wish to thank Mr V. R. Aber for assistance in the statistical analysis of the results and Miss $\mathbf{J}$. A. Kirk for typing the manuscript.

References

Benveniste, R., and Davies, J. (1971). R-factor mediated gentamicin resistance: a new enzyme which modifies aminoglycoside antibiotics. FEBS Letters, 14, 293-296.

Benveniste, R., and Davies, J. (1973). Mechanisms of antibiotic resistance in bacteria. Ann. Rev. Biochem., 42, 471-506.

Clowes, R. C., and Hayes, W. (1968). Experiments in Microbiol Genetics, 1st ed., pp. 187. Blackwell, Oxford and Edinburgh.

Darrell, J. H., and Neale, G. (1972). The treatment of septicaemia due to gram-negative organisms. Prescribers J., 12, 51-57.

Forrey, A. W., Blair, A., O'Neill, M., Cutler, R. E., and Christopher, ¿̨ T. G. (1973). Enzymatic assay for gentamicin. New Engl. J. Med., 288, 108.

Heppel, L. A. (1967). Selective release of enzymes from bacteria. Science, 156, 1451-1455.

Noone, P., Pattison, J. R., and Samson, D. (1971). Simple, rapid I method for assay of aminoglycoside antibiotics. Lancet, 2 , 16-19.

Noone, P., Pattison, J. R., and Slack, R. C. B. (1972). Rapid assay of N gentamicin. Lancet, 2, 1194-1195.

Nossal, N. G., and Heppel, L. A. (1966). The release of enzymes by $\mathrm{N}$ osmotic shock from Escherichia coli in exponential phase. N J. biol. Chem., 241, 3055-3062.

Reeves, D. S. (1972). Assay of gentamicin. Lancet, 2, 1369-1370.

Ruhen, R. W., and Darrell, J. H. (1973). Antibiotic synergism against group D Streptococci in the treatment of endocarditis. Med.o J. Aust., 2, 114-116.

Smith, D. H., Van Otto, B., and Smith, A. L. (1972). A rapid chemical $\mathscr{D}$ assay for gentamicin. New Engl. J. Med., 286, 583-586. 